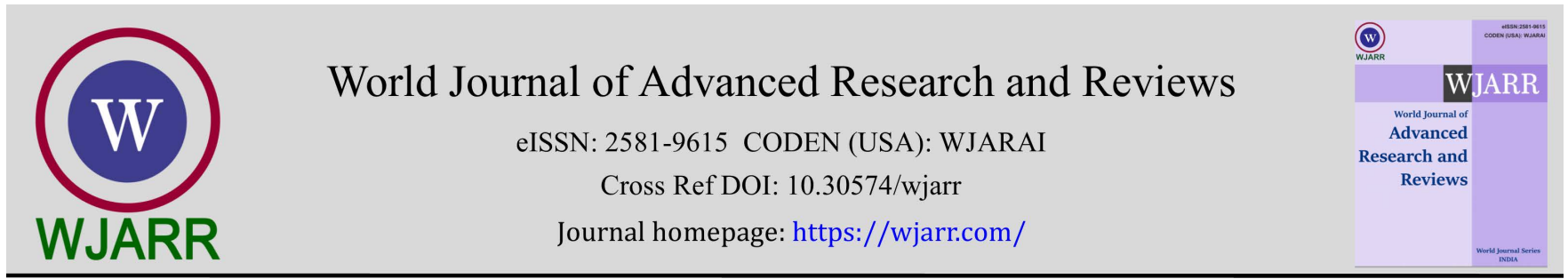

(RESEARCH ARTiCle)

\title{
Corporate social responsibility and management of oil related conflict in Host Communities of Niger Delta Region, Nigeria
}

\author{
Kenneth Chisom Gbali, Vincent Ezikornwor Weli * and Prince Chinedu Mmom \\ Department of Geography and Environmental Management, University of Port Harcourt. P.M.B 5323, East-West Road, \\ Choba, Port Harcourt.
}

World Journal of Advanced Research and Reviews, 2021, 12(02), 421-433

Publication history: Received on 13 October 2021; revised on 15 November 2021; accepted on 17 November 2021

Article DOI: https://doi.org/10.30574/wjarr.2021.12.2.0608

\begin{abstract}
The study sought to examine the Corporate Social (CSR) and management of oil related conflicts in Host Communities of the Southern States. Corporate Social Responsibility is the commitment of businesses to contribute to sustainable economic development by working with employees, the local community and the society at large to improve their lives in ways that are good for business and for development. The study was guided by three research objectives, three research questions and three hypotheses. The design adopted for this study is exploratory and descriptive research design and was conducted in Bayelsa, Delta and Rivers State in Nigeria. The population of this study comprised of 15,245,247 residents in Bayelsa, Delta and Rivers State in Nigeria. The instrument for data collection was a set of structured questionnaire. Data derived from the field were analyzed using the Statistical Package for Social Sciences (SPSS) version 23.0. And statistical tools such as mean and standard deviation were used to respond to the research questions, while inferential statistical tool of independent sample T-test was used to test the hypotheses at 0.05 level of significance. Findings from the study showed that there is a significant difference in the mean ratings of male and female respondents on the level of relationship between IOC's and hosts Communities in Niger Delta Region, Nigeria $((\mathrm{P}=0.738>0.05), \mathrm{df}(400)=.-0.49273, \mathrm{p}=0.738)$; there is a significant difference in the mean ratings of male and female respondents on the on CSR programs carried out by IOCs in hosts Communities in Southern Nigeria $(P=.117>0.05)$, df $(400)=-401.618, p=.117)$; further findings showed that there is a significant difference in the mean ratings of male and female respondents on the Factors causing conflict between oil companies and host communities in Southern, Nigeria $(\mathrm{P}=0.775>0.05)$, df $(400)=382.256 \mathrm{p}=0.775)$. Based on the findings of the study, it was recommended that host communities should be integrated into the planning process, a paradigm shift from planning for to planning with the host Communities, amongst others.
\end{abstract}

Keywords: Corporate Social Responsibility; Oil Related Conflict; Southern Nigeria; Host communities; Oil companies.

\section{Introduction}

The activities of International Oil Companies (IOC's) have raised many concerns and criticisms [1], [2], [3], [4], A series of interests and shareholders in Nigeria have been, keen on benefiting from the fossil fuels that can be exploited, as local elites, local fishers, farmers, traders, youth and women in oil bearing communities among others and multi-national oil corporations have been fighting over this dark nectar in the Niger Delta Region. Immense conflicts and disasters such as explosions, crises, oil spillages, the reduction of arable land, and the destruction of wild life and fish reserves [5]. The increase in unemployment has been blamed on the destruction of the host communities' farmlands due to seismic exploration and drilling waste, thereby increasing poverty even further. Those who have been worse affected for decades have been trying to stand up for themselves, their environment and their basic human and economic rights. [6].

\footnotetext{
${ }^{*}$ Corresponding author: Weli Vincent Ezikornwor

Department of Geography and Environmental Management, University of Port Harcourt. P.M.B 5323, East-West Road, Choba, Port Harcourt.
}

Copyright (C) 2021 Author(s) retain the copyright of this article. This article is published under the terms of the Creative Commons Attribution Liscense 4.0. 
Shell-BP as it was known resumed its oil exploration in Nigeria in 1921, with the search for oil (Black gold) making a remarkable breakthrough in 1956 when oil was discovered in commercial quantities at Oloibiri, in the Brass Division of present day Bayelsa state. Although the conflicts in the Niger Delta Region of Nigeria predates Oil exploration and exploitation, but it has been traced to the advent to Multinational Corporations. [7],(8) traced the conflict in the region to the Akassa Raid of 1895, a protest against British policies and that of the Royal Niger Company (RNC) by the Niger Delta traditional institutions. The two-major economic yet conflict prone eras in the Niger Delta included are the palm and crude oil periods. Both eras were characterized by resource conflict involving the local communities (traditional institutions), foreign experts and the government [9]. [10.(11)] contended that there is a direct link between the host communities' non-participation and the conflict in the Niger Delta Region, which is traceable to the regions historical underpinnings.

In describing the Southern region of Nigeria, [12],(13) argue that the region is undoubtedly the richest part of Nigeria in terms of natural resources. In their view: the area has large oil and gas deposits, as well as extensive forests, good agricultural land and abundant fish resources. Despite the tremendous natural and human resources base, the regions potential for sustainable development remains unfulfilled and its future is being threatened by environmental degradation and deteriorating economic conditions which are not being addressed by past and present policies and actions. Over fifty years of oil development has not brought significant benefits to the region [13], (15).

The bitter experience of the Oil producing areas in Nigeria generally has been both unprecedented and indeed regrettable. Unfortunately, most of the multinational Oil companies operating in the Niger Delta Region of Nigeria have failed to adopt best practices regarding strategies for risk mitigation and compliance with environmental regulations [16](17),(18),(19).

Empirical evidence has shown that most of the organizations in the Oil and gas business in pastwere mostly concerned with making profits and leaving the well-being of local inhabitants in the oil bearing communities to individual acts of charity; hence the development of the concept Corporate Social Responsibility to bridge the gap and mitigate conflicts. The truth is that profit making should not be at the expense of the public. Profit making should be fair and human. [20].

The Concept of Corporate social responsibility (CSR) in the whole World is recent about 60years. Prior to this period, there were different standards and regulations in the areas of Corporate Governance, Corporate ethics, and relationships with competitors, responsibilities towards the society and the Country.[21]. Social policy rules and standards have not been developed at all because there was use of "random approach". However, from the late 60's70's leading U.S and European Companies have started to come to an understanding of the need to unite different elements of corporate policies related to the relationship of the Company with the Environment, and to the development of a single integrated approach to interaction with society? Such a policy on the one hand would have to be associated with the philosophy of the Company, it marketing strategy, and it should meet the expectation of Society.

The early 1970's development of the concept was marked with different thoughts among private sector, Government and Civil Society Organizations depending on the perspective to cover. It has gained new focus and remarkable prominence since the 1980s with a Company running its business responsibly in relation to internal stakeholders (shareholders, employees, customers and suppliers [22].

Businesses are realizing that in order to stay profitable in a rapidly changing environment, they would have to become socially responsible. Therefore, the belief that beyond making profit for the shareholders, business enterprises should also serve the interests of all other stakeholders has culminated into the concept of Corporate Social Responsibility (CSR), [23] [24].Is the persistent commitment by a business organization to ethically behave to contribute maximally to the economic and environment advancement of the quality of life its workforce and the society, particularly the host communities. What is noteworthy is that it has moved beyond local or national arenas and become the subject of global attention.That is the role of business in relationship to the State, Locally and nationally, as well as inter-State institutions or standards; and business performance as a responsible member of the society in which it operates and the global Community. Too often, attaining CSR is understood from the perspectives of business generosity to Community projects and charitable donations, but this fails to capture the most valuable contribution that Company has to take.

[25] asserted in his study that various associations have developed their own definitions of CSR for example Business for social Responsibility (BSR) defines CSR as operating a business in a manner that meets or exceeds the ethical, legal, commercial and public expectations that society has on a business. (Www. BSR. Org) CSR is seen by leadership Companies as more than a collection of discrete practices or occasional gesture, or initiatives motivated by marketing, public relations or other business benefits. It is also said to be long-term pursuit of commercial success based on the creation of value for all the corporation's stakeholders. 
Rather it is viewed as a comprehensive set of policies, practices and programs that integrated throughout business operations, and decision-making process that are supported and rewarded by top management. The World Bank defined CSR as the commitment of businesses to contribute to sustainable economic development by working with employees, the local community and the society at large to improve their lives in ways that are good for business and for development [26].

In the context of developing countries, it has become part of broader debates on development and poverty reduction, particularly in relation to the absence of governance in many areas. The subject matter CSR is the cutting edge of strategic thinking in the business community. Corporate responsibility is almost an inevitable result of societal evolution. The issue has been particularly contested when it comes to the behaviour of oil and gas extracting multinational corporations. Most international Oil companies and its operations in the Niger Delta region of Nigeria have been at the centre of attention; attention here therefore would be focused on the three core Niger Delta States of Rivers, Bayelsa and Delta where prominent and predominance of the IOC's are domiciled. The environmental degradation, continuing conflicts, violence and continued poverty of communities in the Delta have been increasingly scrutinized in relation to activities of major IOC's in the area. Still on the debate on the impact of Transnational Corporation (TNC's) or International oil Company (IOC's) and foreign direct investment (FDI) in developing Countries, [27], underscores this study. Put simply, some emphasize the actual or potential contribution of ICO's to economic and social development via investment, employment, taxation and the transfer of technology, knowledge and skills. Others stress the fact that IOC's have been highly implicated in promoting a style of "development" and North-South relations that have put many developing Countries people and their environment at a serious disadvantage. However, IOC's tend to apply double standards in carrying out their roles within society. Their standard in the western world is different from the standard they adopt in Africa, particularly Nigeria. For example, Shell's inability to plug a leak in the North Sea resulted to the resignation of its US chairman. However, the company's recorded oil spills in Niger Delta in 2009 is estimated at 14,000 barrels per day whereas that of the North Sea was estimated at 1,300 barrels per day. This level of pollution in the Niger Delta has neither resulted in a comprehensive clean-up nor has anyone within the corporate structure taken any responsibility. However, as businesses operate within a society its waste products are also discharged in that same society [28],. [29]. It becomes problematic when the waste is not correctly channelled and social impacts are neglected. As discussed, the violence, poverty and environmental destruction in the Niger Delta is a result of a complex history, in which Shell's oil extraction itself as a leading multinational Oil Company, has played a significant role. Extensive damage to small-scale fishing and farming, which has destroyed livelihoods in the Delta, is a result of the IOC's activities. Furthermore, the SPDC and other IOC's such as Chevron, Mobile, Total etc, has certainly contributed to growing militarism in the region, not simply through generating societal grievances but also by directly supporting and paying community groups to militarize in the hope of protecting the company's infrastructure [30]. Despite this, the Companies treat issues such as environmental destruction and poverty as some pre-existing unfortunate situation that has no causal relationship with the company's activities. This refusal to acknowledge responsibility plays a significant part in contributing to a deep (and historically informed) distrust of Shell in the Delta communities. It is the concern of the current investigation to identify suitable conflict management style to model as done in other parts of the world $[31], .[32]$ to guarantee mutual peaceful coexistence between prospecting companies and their host communities.

A clarification and understanding of the basis on which any proposed course of action is to be undertaken in this area will aid in charting our future paths. Thus, the important elements of this subject would thereby provoke thoughts and debate that will hopefully relate corporate responsibility to the crying need for innovation in our society, and lead to development and widespread application of the principles in Nigeria.

\section{The Problem}

The Niger Delta of Nigeria conflicts and disasters have been given different interpretations by different groups, schools of thought and researchers [33]. Notwithstanding, the divergence of the various views, the people of Niger Delta tend to be highly passionate about the issues of participation in their oil endowed land, A famous human right advocate Ken SaroWiwa, according to him" I'm a man of peace, of ideas, appalled by the abject poverty of my people who live in a richly endowed land, distressed by their economic strangulation, angered by the devastation of their land, their ultimate heritage, anxious to preserve their right to life and a healthy living; determined to usher in a valid claim to civilization".

It has been observed that over the years, the people of Niger Delta region have constantly argued at various fora that resource control and integration are the basis of the problems of the region [34],[35],[36] in study further suggests that as far as the Southern is concerned, the recurrent challenges of violence and restiveness are man induced and as a result of gross negligence, non-integration and mainstreaming of the people, which is the sine qua non for sustainable peace and development in Nigeria. 
That the militarisation of the region has not helped in restoring the much-desired stability in this regard raises a question of the government's conflict management style.In spite of the interventionist measures adopted, the aggrieved communities seem not to beappeased by the Nigerian oil industry. The perception of the people within the host communities of the area is that rather than achieve development, oil production activities in the region has bedevilled the Communities with adverse effects such as environmental degradation, mass poverty, oppression, coupled with cases of human right abuses by both the International oil organizations and Government agencies [37], the absence of workable Cooperate Social Responsibility, institutional and financial mechanism, all tend to have provided the rootcause for agitation and exacerbation of militancy and activism in the region. As most of the conflicts in Southern region has been adduced to be man induced, to minimize and reduce the conflicts that result between Oil producing Companies and host Communities and enable organizations engage in the development of the host communities, the nexus between CSR becomes obvious [38].

This study therefore underscores the direct relationship between CSR and management of oil related conflicts.

Although, there has been claims on an upsurge in "voluntary initiatives" associated with codes of conduct, improvements in environmental management systems, improved health and safety standards, company reporting on social and environmental policy and performance, participation in certification and labelling schemes, an increase in corporate social investment in, for example, community development projects, and philanthropy. Large companies in the Southern such as SPDC seeming to be participating in so-called Global memorandum of Understanding (GMOU), which anchors on "multi-stakeholder initiatives" and "public-private partnerships" with NGOs and governmental or multilateral organizations, which to them seem to represent the concept of CSR; but adoption of CSR was not simply a corporation-led movement. Rather, it was part of a paradigm shift in the thinking of development practitioners within a new world order where 'rolling back' incompetent states provided space for a far greater role for the private sector in all areas of life. Included in this thinking was the potential for self-regulated CSR by industries to contribute to development goals. This think piece has revealed some problems with this thinking. In this particular case, the complex nature of the challenges facing the Southern means that many of the fundamental problems in the region cannot be addressed by major IOCs alone. Secondly, it is clear that major players like SPDC faces severe organizational constraints in designing and implementing successful CSR.

\section{Aim and Objectives}

The aim of this study is to examine the Corporate Social Responsibility and management of Oil related Conflicts in Host Communities of the Niger Delta States.

The Specific Objectives includes the following:

- Examine the level of relationship between the oil companies and the host communities e.g., infrastructure, human capacity building e.g. (knowledge transfer) and in the Niger Delta.

- Investigate the CRS programmes carried out by IOCs in the host communities Southern and their impacts in the areas of operations.

- Ascertain the factors causing conflict between oil companies and host Communities Niger Delta of Nigeria.

\subsection{Research Question}

- What is the level of relationship between the oil Companies and the host Communities Niger Delta of Nigeria?

- What are the CSR programmes carried out by IOCs in the host Communities of Niger Delta Nigeria?

- What are the factors causing conflict between oil companies and host Communities Niger Delta of Nigeria?

\subsection{Hypotheses}

The following hypotheses was formulated based on the objectives and problems of this research.

\subsection{1. $\mathrm{HO}_{1}$}

There is no significant difference in the mean rating of male and female respondents on the relationship between IOC's and host Communities in Niger Delta Region

\subsection{2. $\mathrm{HO}_{2}$}

There is no significant difference in the mean ratings of male and female respondents on the CSR programs carried out by the IOCs in the host Communities of Niger Delta. 


\subsection{3. $\mathrm{HO}_{3}$}

There is no significant difference in the mean ratings of male and female respondents' on factors causing conflict between oil companies and host communities in Niger Delta, Nigeria

\subsection{Conceptual Review}

\subsubsection{Corporate Social Responsibility (CSR)}

The definition of modern concept of CSR has varied in different continents, as various schools of thought view the concept with multiple meanings generated by different way of defining the term and the interest intended at the time. Business Dictionary defines it as a company's sense of responsibility towards the community and environment (both ecological and social) in which it operates. [39], gathered the definitions of CSR and submits them to a constant analysis intended to identify their common issues and particularities. One of the wide range of issues, corporations are encouraged to behave socially responsible [40], [41].[42].

The title corporate social responsibility has two meanings. First, it's a general name for any theory of the corporation that emphasizes both the responsibility to make money and the responsibility to interact ethically with the surrounding community. Second, corporate social responsibility is also a specific conception of that responsibility to profit while playing a role in broader questions of community welfare.

As a specific theory of the way corporations interact with the surrounding community and larger world, corporate social responsibility (CSR) is composed of four obligations: The economic responsibility to make money, the legal responsibility to adhere to rules and regulations, the ethical responsibility to do what's right even when not required by the letter or spirit of the law and the philanthropic responsibility to contribute to society's projects even when they're independent of the particular business. Regardless, corporate social responsibility means every business holds four kinds of obligations and should respond to them in order: first the economic, then the legal, next the ethical, and finally the philanthropic.

\subsubsection{Corporate Social Responsibility in the Exploration Industry}

[43],.[44] outline several reasons why CSR and other such voluntary initiatives are important for exploration companies. For IOC's, CSR is the manifestation of a move towards greater sustainability in the industry i.e. the practical implementation of the goals of sustainability. CSR is a means by which companies can frame their attitudes and strategies towards, and relationships with, stakeholders, be they investors, employees or, communities, within a popular and acceptable concept. In the industry, progress within the three dimensions of sustainable development (economic, environmental and social) could be achieved through - economic development - investment of generated revenues to ensure the future development and long-term livelihood of the communities. Environmental protection minimising the environmental impact of natural resource exploitation and land rehabilitated to allow successive use [45]; and social cohesion - reducing the social and cultural disruption to communities, maintenance of stakeholder dialogue and transparency of operation (ibid.). In their efforts to embrace CSR, companies must identify the interests, concerns and objectives of various stakeholders (including national, regional government, local authorities, indigenous people, local communities, employees and competitors) and address their often-varying needs [46].

There are a number of business reasons aside from external pressure why Multinational companies invest in communities through their CSR programmes. [47] outlines these as: Obtaining a competitive advantage - community investment programmes are used to aid the awarding of concessions as companies appearing to be socially responsible are often favoured in this process, Receiving and maintaining a stable working environment - CSR initiatives are occasionally initiated as a means of 'buying' the local communities' agreement to allow a company to operate, Managing external perceptions and maintaining a good reputation - CSR initiatives are used for PR purposes and keeping employees happy - CSR initiatives can often make staff feel more positive about the company, and can increase motivation and efficiency. They can also help to retain and recruit the best staff. A key stakeholder for all Multinational companies, and therefore a strong focus for their CSR initiatives, is 'the community'.

\section{Methodology}

This study employed the exploratory and descriptive research design and the study was conducted in all Niger Delta states which comprises of six States including; Delta, Edo, Bayelsa, Rivers, Cross Rivers and Akwa Ibom State. The population of the study comprised of 15,245,247 residents in Bayelsa, Delta and Rivers State in Nigeria [36]. The sample size for the study was four hundred (400) and this was determined using the Taro Yamane formula. The multi-stage 
sampling technique which comprised of stratified sampling, random sampling, and purposive sampling were used to select four hundred respondents from the population for the study. Data for the study was derived via primary and secondary data sources. Primary data was derived using a set of structured questionnaires, interview, and Focused Group Discussion. Secondary data for the study was derived from published project material, journals, newspapers, and online blogs, amongst others.

The main method for data collection used in this study was structured questionnaire, semi-structured interviews, participant observation, group discussion, secondary source analysis and questionnaires. The instruments for the study were validated through constructive suggestions by the supervisor for corrections and final approval, and the reliability of the instrument was determined using the Cronbach Alpha reliability test, and a reliability coefficient of 0.87 was derived. Data derived from the study were sorted, coded and analysed using the Statistical Package for Social Sciences (SPSS) version 23.0. Descriptive statistical tools such as mean and standard deviation were used to respond to the research questions, while inferential statistical tool independent sample T-test was used to test the hypotheses.

\section{Data Presentation and Analysis}

\subsection{Research Question 1}

What is the level of relationship between the oil Companies and the host Communities of Niger Delta in Nigeria?

Table 1 Mean ratings of respondents on the level of relationship between the oil Companies andthe hostCommunities of Niger Delta region?

\begin{tabular}{|c|c|c|c|c|}
\hline $\mathbf{S} / \mathbf{N}$ & Items & $(\mathrm{X})$ & SD & Decision \\
\hline 1 & $\begin{array}{l}\text { Oil companies regularly hold meetings with host communities on specific issues } \\
\text { relating them }\end{array}$ & 2.82 & 0.89 & $\mathrm{H}$ \\
\hline 2 & Oil companies enter into MOU with host communities on developmental issues & 2.87 & 0.89 & $\mathrm{H}$ \\
\hline 3 & Host communities jointly participate in protecting facilitiesof oil companies & 2.74 & 0.87 & $\mathrm{H}$ \\
\hline 4 & Oil companies have severally provided host communities with social infrastructures & 2.98 & .077 & $\mathrm{H}$ \\
\hline 5 & $\begin{array}{l}\text { Host communities have always reported cases to police carried out by hoodlums on } \\
\text { oil company facilities. }\end{array}$ & 2.03 & 0.94 & $\mathrm{~L}$ \\
\hline 6 & $\begin{array}{l}\text { Oil companies have severally appreciated host communities for securing their } \\
\text { facilities }\end{array}$ & 2.93 & 0.76 & $\mathrm{H}$ \\
\hline \multicolumn{2}{|r|}{ Grand Mean } & 2.74 & 0.85 & $\mathrm{H}$ \\
\hline
\end{tabular}

Table 1 showed the mean ratings of respondents on the level of relationship between the oil Companies and the host Communities of Niger Delta region. Findings from the table showed a cluster mean and standard deviation scores of 2.74 and 0.85 which means that respondents are of the view that the level of relationship between the oil Companies and host Communities of Nigeria is high.

\subsection{Research Question 2}

Table 2 Mean ratings of respondents on the CSR programs carried out by IOCs in the host Communities of Niger Delta of Nigeria?

\begin{tabular}{|c|l|c|c|c|}
\hline S/N & \multicolumn{1}{|c|}{ Items } & (X) & SD & Decision \\
\hline 1 & Build health care facilities for host communities & 2.64 & 0.96 & $\mathrm{~A}$ \\
\hline 2 & Carry out environmental support programmes for enhance living & 2.78 & 0.87 & $\mathrm{~A}$ \\
\hline 3 & Provide welfare and support to the aged and poor & 2.56 & 0.96 & $\mathrm{~A}$ \\
\hline 4 & Provide legal services to host communities & 2.49 & 0.74 & $\mathrm{~A}$ \\
\hline 5 & Provide education programs to children and youths & 2.74 & 0.99 & $\mathrm{~A}$ \\
\hline 6 & Provide economic empowerment for members of host communities & 2.78 & 0.85 & $\mathrm{~A}$ \\
\hline \multicolumn{2}{|c|}{ Grand Mean } & 2.67 & 0.89 & $\mathrm{~A}$ \\
\hline
\end{tabular}


What are the CSR programs carried out by IOCs in the host Communities of Niger Delta Region of Nigeria?

The mean ratings of respondents on the on the CSR programs carried out by IOCs in the host Communities of Niger Delta region are shown in table 2 . The table showed a grand mean and standard deviation scores of 2.67 and 0.89 which implies that respondents agree that the CSR programs carried out by IOCs in the host Communities of Niger Delta region of Nigeria are: building health care facilities, environmental support programmes for host communities, providing welfare and support to the aged and poor in host communities, providing education programs to children and youths, and providing economic empowerment for members of host communities.

\subsection{Research Question 3}

What are the factors causing conflict between oil companies and host Communities Niger Delta region of of Nigeria?

Table 3 Mean ratings of respondents on the factors causing conflict between oil companies and host communities Niger Delta region

\begin{tabular}{|c|c|c|c|c|}
\hline $\mathbf{S} / \mathbf{N}$ & Items & $(\mathrm{X})$ & SD & Decision \\
\hline 1 & Lack of compensation to host communities & 2.74 & 0.92 & $\mathrm{~A}$ \\
\hline 2 & Neglect of host communities by oil companies & 2.84 & 0.82 & A \\
\hline 3 & Environmental degradation of host communities & 2.75 & 0.77 & A \\
\hline 4 & Oil exploration activities of oil companies & 2.74 & 0.89 & A \\
\hline 5 & Lack of community participation in decision making on issues that affects them & 2.77 & 0.84 & A \\
\hline 6 & Excessive pursuit of profit by oil companies to the detriment of host communities & 2.63 & 0.97 & A \\
\hline 7 & Non-implementation of SCR to host communities & 2.77 & 0.84 & A \\
\hline \multicolumn{2}{|r|}{ Grand Mean } & 2.75 & 0.86 & A \\
\hline
\end{tabular}

Dec=Decision; $A=$ Agree

Table 3 showed the mean ratings of respondents on the factors causing conflict between oil companies and host communities of Niger Delta region. The table displayed a cluster mean and standard deviation scores of 2.75 and 0.86 which entails that respondents agree that the factors causing conflict between oil companies and host communities Niger Delta region of Nigeria are: lack of compensation to host communities, neglect of host communities by oil companies, environmental degradation of host communities, oil exploration activities of oil companies, lack of community participation in decision making on issues that affects them, excessive pursuit of profit by oil companies to the detriment of host communities, and non-implementation of SCR to host communities.

\subsection{Test of Hypotheses}

\subsection{1. $\mathrm{HO}_{1}$}

There is no significant difference in the mean rating of male and female respondents on the level of relationship between IOC's and host Communities in Niger Delta region.

Table 4 showed that the group means are statistically insignificant because the value for equal variance assumed in the sig. (2-tailed) row is greater than 0.05 that is $(\mathrm{P}=0.738>0.05)$, $\mathrm{df}(400)=.-0.49273, \mathrm{p}=0.738$. Therefore, the null hypothesis of no significant difference in the mean rating of male and female respondents on the level of difference between IOC's and host Communities in Niger Delta region of Nigeria is rejected. This implies that there is a significant difference in the mean ratings of male and female respondents on the level of relationship between IOC's and hosts Communities in Niger Delta region of, Nigeria. 
Table 4 Independent Samples Test for male and female respondents on the level of relationship between IOC's and host Communities in Niger Delta region

\begin{tabular}{|c|c|c|c|}
\hline & & \multicolumn{2}{|c|}{$\begin{array}{c}\text { Level of relationship b/w IOC's \& } \\
\text { hostcommunities }\end{array}$} \\
\hline & & $\begin{array}{c}\text { Equal } \\
\text { variance } \\
\text { assumed }\end{array}$ & $\begin{array}{c}\text { Equal } \\
\text { variancenot } \\
\text { assumed }\end{array}$ \\
\hline \multirow{2}{*}{$\begin{array}{c}\text { Lavene's Test for Equality } \\
\text { of } \\
\text { Variances }\end{array}$} & $\mathbf{F}$ & 0.035 & \\
\hline & Sig. & 0.851 & \\
\hline \multirow[t]{7}{*}{ t-test for Equality of Means } & $\mathrm{t}$ & -0.335 & -0.331 \\
\hline & $\mathrm{df}$ & 401 & 366.413 \\
\hline & Sig.(2-tailed) & 0.005 & 0.741 \\
\hline & Mean Difference & -0.07107 & -0.07107 \\
\hline & Std. Error Difference & 0.21226 & $0.21443-0.49273$ \\
\hline & 95\% Confidence Lower & -0.48835 & 0.35060 \\
\hline & $\begin{array}{l}\text { interval of the difference } \\
\text { Upper }\end{array}$ & 0.34622 & \\
\hline
\end{tabular}

\subsection{2. $\mathrm{HO}_{2}$}

There is no significant difference in the mean ratings of male and female respondents on the CSR programs carried out by the IOCs in the host Communities of Niger Delta region.

Table 5 Independent Samples Test for male and female respondents on CSR programs carried out by the IOCs in the host Communities of Niger Delta region

\begin{tabular}{|c|c|c|c|}
\hline & & \multicolumn{2}{|c|}{ CSR programs carried in hostcommunities } \\
\hline & & $\begin{array}{l}\text { Equal } \\
\text { variance } \\
\text { assumed }\end{array}$ & $\begin{array}{l}\text { Equal } \\
\text { variancenot } \\
\text { assumed }\end{array}$ \\
\hline $\begin{array}{l}\text { Lavene's Test for Equality of } \\
\text { Variances }\end{array}$ & $\begin{array}{l}\text { F } \\
\text { Sig. }\end{array}$ & $\begin{array}{l}1.185 \\
0.277\end{array}$ & \\
\hline \multirow{7}{*}{ t-test for Equality of Means } & $\mathrm{t}$ & -1.569 & -1.574 \\
\hline & df & 402 & 401.618 \\
\hline & Sig.(2-tailed) & 0.005 & 0.116 \\
\hline & Mean Difference & -0.33893 & 0.21531 \\
\hline & Std. Error Difference & 0.21226 & 0.21443 \\
\hline & 95\% ConfidenceLower & 0.76364 & 0.76220 \\
\hline & interval of the differenceUpper & 0.08577 & 0.08433 \\
\hline
\end{tabular}

Table 5 showed that the group means are statistically insignificant because the value for equal variance assumed in the sig. (2-tailed) row is greater than 0.05 that is $(\mathrm{P}=.117>0.05)$, $\mathrm{df}(400)=.-0.401 .618, \mathrm{p}=0.117$. Therefore, the null hypothesis of no significant difference in the mean rating of male and female respondents on CSR programs carried out 
by IOCs in host Communities in Nigeria is rejected. This implies that there is a significant difference in the mean ratings of male and female respondents on the on CSR programs carried out by IOCs in hosts Communities in Niger Delta region of Nigeria.

\subsection{3. $\mathrm{HO}_{3}$}

There is no significant difference in the mean ratings of male and female respondents' on factors causing conflict between oil companies and host communities in Niger Delta region of Nigeria.

Table 6 Independent Samples Test for male and female respondents on CSR programs carried out by the IOCs in the host Communities of Niger Delta region of Nigeria

\begin{tabular}{|c|c|c|c|}
\hline & & \multicolumn{2}{|c|}{$\begin{array}{l}\text { Factors causing conflict between oil companies and } \\
\text { host communities }\end{array}$} \\
\hline & & $\begin{array}{c}\text { Equal variance } \\
\text { assumed }\end{array}$ & $\begin{array}{l}\text { Equal Variance not } \\
\text { assumed }\end{array}$ \\
\hline $\begin{array}{c}\text { Lavene's Test for } \\
\text { Equality of } \\
\text { Variances }\end{array}$ & $\begin{array}{c}\text { F } \\
\text { Sig. }\end{array}$ & $\begin{array}{c}0.05 \\
0.904\end{array}$ & \\
\hline \multirow{7}{*}{$\begin{array}{l}\text { t-test for Equality of } \\
\text { Means }\end{array}$} & $\mathrm{t}$ & 0.286 & 0.291 \\
\hline & $\mathrm{df}$ & 402 & 382.256 \\
\hline & Sig.(2-tailed) & 0.005 & 0.771 \\
\hline & Mean Difference & 0.09640 & 0.09640 \\
\hline & Std. Error Difference & 0.33672 & 0.33138 \\
\hline & 95\% Confidence Lower & -0.56554 & -0.55516 \\
\hline & $\begin{array}{l}\text { interval of the difference } \\
\text { Upper }\end{array}$ & 0.75835 & 0.74796 \\
\hline
\end{tabular}

Table 6 showed that the group means are statistically insignificant because the value for equal variance assumed in the sig. (2-tailed) row is greater than 0.05 that is $(\mathrm{P}=.775>0.05)$, d.f. $(400)=382.256 \mathrm{p}=0.775$. Therefore, the null hypothesis of no significant difference in the mean ratings of male and female respondents on factors causing conflict between oil companies and host communities in Niger Delta region is rejected. This implies that there is a significant difference in the mean ratings of male and female respondents on the Factors causing conflict between oil companies and host communities in Niger Delta region.

\section{Discussion of Findings}

\subsection{Level of relationship between the oil Companies and host Communities}

The findings in this regard showed that the level of relationship between the oil Companies and host Communities in Niger Delta region is high. This was based on the fact that oil companies hold meetings with host communities on specific issues relating them, oil companies enter into MOU with host communities on developmental issues, host communities jointly participate in protecting facilities of oil companies, Oil companies have severally provided host communities with social infrastructures, and oil companies have severally appreciated host communities for securing their facilities. The test of the null hypotheses in this respect showed that there is a significant difference in the mean ratings of male and female respondents on the level of relationship between IOC's and hosts Communities in Niger Delta region. These findings agree with the assertion of [48] who stated that most of the conflicts in Niger Delta region has been adduced to be man induced, hence to minimize and reduce the conflicts that result between Oil producing Companies and host Communities there is need for a holistic approach for the development of the host communities and involving them on discussions related to their needs. Also, in line with the findings, [49] stated that cultural and leadership variables associated with corporate social responsibility values that should be applied in decision-making related to development of host communities. This is because; corporate social responsibility is a major factor for lasting development and relationship in a global economic society. 


\subsection{CSR programs carried out by IOCs in the host Communities of Niger Delta region of Nigeria}

The findings in this regard showed that The CSR programs carried out by IOCs in the host Communities of Niger Delta region are: building health care facilities, environmental support programmes for host communities, providing welfare and support to the aged and poor in host communities, providing education programs to children and youths, and providing economic empowerment for members of host communities. The findings in the test of hypotheses showed that there was a significant difference in the mean ratings of male and female respondents on the on CSR programs carried out by IOCs in hosts Communities in Niger Delta region of, Nigeria. The difference in their opinion may be in individual perception and the level of operation of oil companies in the area. These findings relate to that assertion of [50] who stated that corporate social responsibility, believes that firms are obligated to satisfy their economic responsibility to make money for the firm by protecting their investments, while also acting legally. Further, the Companies needed to satisfy the ethical responsibility to help host communities in the operational areas to get their good lives back. Further congruent assertions to the findings according to [51]. [52], is that CSR initiatives are occasionally initiated as a means of 'buying' the local communities' agreement to allow a company to operate, managing external perceptions and maintaining a good reputation - CSR initiatives are used for PR purposes and keeping employees happy - CSR initiatives can often make staff feel more positive about the company, and can increase motivation and efficiency. They can also help to retain and recruit the best staff. A key stakeholder for all Multinational companies, and therefore a strong focus for their CSR initiatives, is the community. [53], [54] highlighted some CSR programs carried in oil producing communities as follows: infrastructural improvement like, building access roads, community buildings, and schools; Community Health Initiatives like offering health services to employees and their families, and building and equipping hospitals and health centres for communities; Community foundations a fund generated by the company that is used for social investment purposes which can attract interest from external donors; supporting small local businesses - preferential procurement policies for local suppliers; and sustainable livelihood projects.

\subsection{Factors causing conflict between oil companies and host communities Of Niger Delta region of Nigeria}

The findings in this respect showed that The factors causing conflict between oil companies and host communities Of Niger Delta region, Nigeria are: lack of compensation to host communities, neglect of host communities by oil companies, environmental degradation of host communities, oil exploration activities of oil companies, lack of community participation in decision making on issues that affects them, excessive pursuit of profit by oil companies to the detriment of host communities, and non-implementation of CSR to host communities. The test of hypotheses revealed that there is a significant difference in the mean ratings of male and female respondents on the factors causing conflict between oil companies and host communities in Of Niger Delta region, Nigeria. The difference in mean opinion may depend on the individual and type of companies and the CSR programs carried out in the communities of the respondents that may warrant the nature of conflict. In line with these findings, [55] posited that corporations trying to get away with polluting the environment or other kinds of objectionable actions may, it's true; increase their bottom line in the short term to reduce conflict. Looking further out, however, there's a risk that a later discovery of the action could lead to catastrophic economic consequences. This possibility leads immediately to the conclusion that concern for corporate sustainability in financial terms argues against the neglecting host communities from been developed.

It is concluded from the findings of the study that oil related conflicts are inevitable in host communities if oil companies obviate from their social responsibilities. An all-inclusive participation of host communities in the decision-making process of oil companies on issues pertaining to them is essential for cordial relationship. It is for such correction and proactive crisis prevention measures that functional CSR (Corporate Social Responsibility) Department is established in every Fortune 500 companies.

\section{Conclusion}

It is concluded from the findings of the study that oil related conflicts are inevitable in host communities if oil companies obviate from their social responsibilities. An all-inclusive participation of host communities in the decision-making process of oil companies on issues pertaining to them is essential for cordial relationship. It is for such correction and proactive crisis prevention measures that functional CSR (Corporate Social Responsibility) Department is established in every Fortune 500 companies.

\section{Recommendations}

Based on the findings of the study, the following recommendations were made;

- To reduce oil related conflicts in host communities, oil companies should ensure that their social 
responsibility policies are implemented effectively.

- Host communities should be integrated into the planning process, a paradigm shift from planning for to planning with the host Communities.

- Every IOC should establish a Department CSR for the correction and proactive crisis prevention measures.

\section{Compliance with ethical standards}

\section{Acknowledgments}

We wish to acknowledge the support of the oil companies and host communities for their cooperation in the release of vital information that aided this study.

\section{Disclosure of conflict of interest}

There is no conflict of interest among the authors in this study.

\section{Statement of informed consent}

Informed consent was obtained from the oil companies and the host communities before the commencement of this study.

\section{References}

[1] Human Right Watch. The Price of Oil: Corporate Responsibility and Human Rights Violations in Nigeria's Oil Producing CommunitiesArchived May 27, 2016, at the Wayback Machine (Human Rights Watch, 1999).

[2] Austin D, Sauer A. 'Changing Oil: Emerging Environmental Risks and Shareholder Value in the Oil and Gas Industry' (Washington, DC: World Resources Institute. 2002.

[3] Nwilo PC, Badejo OT. Oil Spill Problems and Management in the Niger Delta. International Oil Spill Conference Proceedings. Department of Surveying \& Geoinformatics. 2005: 567-570.

[4] Blowfield M. Corporate Social Responsibility: Reinventing the meaning of development? 81 International Affairs. 2005; 3: 515-524 at 522 .

[5] Lorne S, James M, Andrew R. The Next Gulf: London,Washington and Oil Conflict in Nigeria. Constable \& Robinson Ltd. 2005.

[6] Peel, Michael (24 Mar 2011). A Swamp Full of Dollars: Pipelines and Paramilitaries at Nigeria's Oil Frontier (illustrated, reprint ed.). I.B.Tauris. 2011.

[7] Odera O. Corporate social responsibility reporting of local oil companies in Nigeria, International Journal of Law and Management. 2011; 63(1): 35-50.

[8] Koos, Carlo; Pierskalla Jan. The Effects of Oil Production and Ethnic Representation on Violent Conflict in Nigeria: A Mixed-Methods Approach". Terrorism and Political Violence. 2005; 28(5): 888-911.

[9] Ako R, Obokoh L, Okonmah P. Forging peaceful relationships between oil-companies and host-communities in Nigeria's Delta region: A stakeholder's perspective to corporate social responsibility. Journal of Enterprising Communities: People and Places in the Global Economy. 2009; 3(2): 205-216.

[10] Okonta S, Kemdi D. Economics of violence: Petroleum politics and community conflicts in the Nigeria Delta, Nigeria. 2004.

[11] Okoye A. Theorising corporate responsibility as an essentially contested concept: $\quad$ Is $\quad$ a definition.. necessary? Journal of Business Ethics. 2009; 89(4): 613-627.

[12] Omeje KC. High stakes and stakeholders: Oil conflict and security in Nigeria. Aldershot: Ashgate. 2006.

[13] Muthuri JN. Corporate social responsibility in Africa: Definition, issues and processes. Royal Holloway University of London School of Management Research Seminar.

[14] Kivuitu M, Yambayamba K, Fox T. How can corporate social responsibility deliver in Africa? Insights from Kenya and Zambia. IIED Perspectives on Corporate Responsibility for Environment and Development. 2015; 3(7): $1-5$. 
[15] Idemudia U. Corporate social responsibility and development in Africa: Issues and possibilities. Geography Compass. 2014; 8(7): 421-435.

[16] Friuza M. History and development of Corporate social responsibility. Journal of Business and Economics. 2013; 4(6): 56.

[17] Idemudia U. Rethinking the role of corporate social responsibility in the Nigerian oil conflict: The limits of CSR. Journal of International Development. 2010; 22(7): 833-845.

[18] Ite A, Ibok UJ, Ite S, Peters W. Petroleum exploration and production: past and present. Environmental issues in the Nigeria's Niger Delta. Lancaster environment centre, Lancaster University, Lancaster, United Kingdom. 2013.

[19] Reyes M. Corporate Social Responsibility and Environmental Management at the World bank. 2002.

[20] Ogbemi O Brickins. Corporate social responsibility as a conflict management strategy in selected oil producing communities in Delta State. A research dissertationpg. 2017; 37.

[21] Frynas J. Beyond corporate social responsibility: Oil multinationals and social challenges.Cambridge University Press. 2009.

[22] Asgill S. The Nigerian Extractive Industries Transparency Initiative (NEITI): Tool for Conflict Resolution in the Niger Delta or Arena of Contested Politics?" Critical African Studies. 2015; 7: 4-57.

[23] Ananaba U, Chukwuka E. Corporate Social Responsibility and Its Implementation in Nigeria Problem and Prospects. Global Journal of Human Resources Management. 2016; 4(2): 66-69.

[24] Gouldson A. Do firms adopt lower standards in poorer areas? Corporate social responsibility and environmental justice in the EU and the US. Area. 2006; 38(4): 402-412.

[25] Ako RT. Enforcing environmental rights under Nigeria's 1999 Constitution: The localisation of human rights in the Niger Delta region. In Feyter, K. de, et al. (Eds.), The local relevance of human rights (pp. 72-104). New York: Cambridge University Press. 2011.

[26] Lantos GP. The boundaries of strategic corporate social responsibility. Journal of Consumer Marketing. 2011; 18(7): 595-630.

[27] Oyefusi S. Oil and the Probability of Rebel Participation among youths in the Niger Delta. 2007.

[28] Ibeanu O. Oil, Conflicts, And security in rural Nigeria: issues in Ogoni crises. 1999.

[29] Akpan W. Between responsibility and rhetoric: Some consequences of CSR practice in Nigeria's oil province. Development Southern Africa. 2006; 23(2): 223-240.

[30] Asgill S. The Nigerian Extractive Industries Transparency Initiative (NEITI): Tool for Conflict Resolution in the Niger Delta or Arena of Contested Politics?" Critical African Studies. 2012; 7: 4-57.

[31] Hans A, Bariki AS. Conflict management styles in oil and gas sector in Sultanate of Oman. International Journal of Information Technology and Business Management. 2012; 4(1): 1-15.

[32] Sánchez LE. Industry response to the challenge of sustainability: the case of the Canadian nonferrous mining sector. Environmental Management. 1998; 22(4): 521-531.

[33] Frynas J. The false development promise of Corporate Social Responsibility: Evidence from Multinational Oil Companies. International Affairs. 2005; 81(3): 581-598.

[34] Obi C, Siri AR. Oil and insurgency in the Niger Delta: managing the complex politics of petro-violence. London: Zed Books. 2011.

[35] Peter U. Promoting development through Corporate Social Responsibility- Does it work? International Journal of Social Science. 2003; 1(6): 21-22.

[36] Okonta\&kemdi. Economics of violence: Petroleum politics and Community conflicts in the Niger Delta,. Nigeria. 2004.

[37] Oyefusi. Oil and the probability of rebel participation among Youth in the Niger Delta. 2007.

[38] National Population Commission of Nigeria. Population data for states of the Niger Delta Region. 2006.

[39] Alexander D. a comparative study of CSR strategies in the Oil and Gas industry. 2006. 
[40] Idemudia U, Ite U. Corporate-community relations in Nigeria's oil industry: Challenges and imperatives. Corporate Social Responsibility and Environmental Management. 2006; 13(4): 194-206.

[41] Henderson D. Misguided virtue: False notions of corporate social responsibility. Hobart Paper, 142. London: Institute of Economic Affairs. 2001.

[42] Campbell JL. Why would corporations behave in socially responsible ways? An institutional theory of corporate social responsibility. Academy of Management Review. 2007; 32(3): 946-967.

[43] Walker J, Howard S. Voluntary codes of conduct in mining industry. Minerals and sustainable development (MMSD). 2002.

[44] Edoho FM. Oil transnational corporations: Corporate social responsibility and environmental sustainability. Corporate Social Responsibility and Environmental Management. 2008; 15(4): 210-222.

[45] Sánchez LE. Industry response to the challenge of sustainability: the case of the Canadian nonferrous mining sector. Environmental Management. 1998; 22(4): 521-531.

[46] Guerra MCG. Community relations in mineral development, The CEMPLP Internet journal. 2002; 11: 1-31.

[47] Frynas, Jedrzej George. 'Corporate Social Responsibility in the Oil and Gas Sector', Journal of World Energy Law \& Business 2(3). 2009; 178-195.

[48] Osagiea A. Causes of conflicts in the Niger Delta Region of Nigeria as expressed by the Youth in Delta State. 2010.

[49] David SL. effectiveness corporate social responsibility on Human development. 2012.

[50] Walker J, Howard S. Voluntary codes of conduct in mining industry. Minerals and sustainable development (MMSD). 2002.

[51] Hillson G, Murck B. progress towards pollution prevention and waste minimization in North America Gold mining industry. Journal of cleaner production. 2001; 9(5): 405-415.

[52] Cottrell G, Rankin L. creating business value through corporate sustainability; sustainability strategies and reporting. 2000.

[53] Corporate social responsibility as a tool for maintaining peace in society- A study of Kaduna Refinery and Petrochemical Company, Kaduna State.

[54] Akanwa PU, Agu CN. the politics of conflict over Oil in the Niger Retteh and Mellahi. 2010.

[55] Ledwidge J. Corporate social responsibility: the risks and opportunities for HR. Human Resource Management International Digest. 2007. 